\title{
Urban English Learners' Perceptions Towards the Influence of Second Language Identity on Employment Opportunities in Malaysia
}

\author{
Minder Kaur Parthaman Singh ${ }^{1 *}$, Jo Yee Liew ${ }^{1}$, and Ching Sin Siau ${ }^{2}$ \\ ${ }^{1}$ Department of English Language \& Communication, Faculty of Social Sciences \& Liberal Arts, \\ UCSI University, Kuala Lumpur Campus, 56000 Cheras, Kuala Lumpur, Malaysia \\ ${ }^{2}$ Centre for Community Health Studies (ReaCH), Faculty of Health Sciences, Universiti Kebangsaan Malaysia, \\ 50300, Kuala Lumpur, Malaysia
}

\begin{abstract}
The purpose of this study was to identify and investigate urban English learners' perceptions towards their second language identity in Malaysia and the influence of the said identity on their employment opportunities in Malaysia. This research was an exploratory study that employed a qualitative research design. The data was analysed for second language identity development factors and participants' perception on the influence of their English language identity on their employment opportunities. The second language identity development factors identified were personal, social, professional, educational and learning environment. These factors were found to have influenced the participants' second language identity development. The participants' perception on the influence of their English language identity on their employment opportunities were analysed and discussed. This study has implications for studies on English language proficiency and employment opportunities in Malaysia as well as providing English educators with a different outlook on the resources used to teach English learners.

ARTICLE INFO

Article history:

Received: 3 August 2020

Accepted: 12 November 2020

Published: 26 March 2021

DOI: https://doi.org/10.47836/pjssh.29.1.02

E-mail addresses:

minderkaj@gmail.com (Minder Kaur Parthaman Singh)

jo_yee@hotmail.my (Jo Yee Liew)

chingsin.siau@gmail.com (Ching Sin Siau)

*Corresponding author

Recommendations for future studies include conducting a long-term project that involves participants noting down their narratives such as a photo-elicitation project, to use as data for furthering this research.

Keywords: Employment opportunities, English language proficiency, perceptions, second language identity, urban English learners
\end{abstract}




\section{INTRODUCTION}

Urban English learners live in an environment where they are often in contact with the English language, thus have the opportunity to practice it, as reported by Gobel et al. (2013). Urban areas provide opportunities for learning and include a plethora of experiences which build skills. Glaeser (1999) stated that the scale of economies allowed by urban areas grant better schools to be built, therefore facilitating the delivery of formal education. Hanapi and Nordin (2014) had noted that graduate unemployment in Malaysia was prevalent and it was often tied to the quality of their English language mastery. This suggests that urban English learners should have a high awareness of their second language identity since English learning resources may influence English learners and generally affect second language identity development as shared by Besser and Chik (2014). This ties in as such that urban English learners' second language identity may play a role in their employment opportunities.

However, most urban English learners in Malaysia are not aware of their second language identity nor the influence it may have on their employment opportunities. Sarudin et al. (2008) had found that most studies on English language proficiency among Malaysian university graduates often resonated a feeling of uneasiness with the graduates' level of English proficiency. More recently, Selvaratnam (2019) pointed out that the primary reason that one in five of the 200,000-yearly public university graduates were unemployed might be due to their poor English language proficiency. The decline in English proficiency has been attributed to patriotic sentiments emphasizing the fusion of language-usage with national identity (Selvaratnam, 2019).

The rejection of learning the English language due to identity issues could in turn jeopardise an individual's job opportunities, especially as English language is considered to be important among employers (e.g., Ting et al., 2017; Zainuddin et al., 2019). According to Sekharan Nair et al. (2012), the lack of English proficiency may lead to occupational segregation and affect employment prospects in Malaysia. If this persists, there will be limitations to urban English learners' employment opportunities as there will be a lack of awareness of one's second language identity as well as the influence it may have on employment prospects. As such, this study aims to answer two research questions (RQ), as follows:

RQ1: How do urban English learners perceive their identity as second language learners and factors leading to its development?

RQ2: How do urban English learners perceive the influence of second language learner identity on employment opportunities in Malaysia?

\section{Theoretical Background}

Recent research has discovered urban/rural and class differences in self-perception of intelligence, and differences in educational goals and academic achievement. Swami 
and Furnham (2010) found in a nationwide study of self-assessed intelligence, that urban participants tended to have higher self-assessments than their rural counterparts. Kudrna et al. (2010) found parallel results regarding the connection between social class and self-assessed intelligence, with participants of a high social class having significantly higher self-assessments when their social class was salient. Baharudin et al. (2010) found that academic goals and academic achievement also varied based on location. In addition, urban students of the English language are exposed to more vocabulary learning strategies compared to rural students $(\mathrm{Ab}$ Dollah \& Shah, 2016), which may lead to better proficiency. These studies suggest that urban English learners should have high awareness of their second language identity since English learning resources may influence English learners and generally affect second language identity development (Besser \& Chik, 2014).

Second language identity is defined in a study by Benson et al. (2013) as "any aspect of a person's identity that is linked to their knowledge or use of a second language" (p. 28), and according to De Fina (2012), identities can be regarded as collective or individual, as social or personal, as mental constructs or as the product of actions. According to Norton and Mckinney (2011), the 'identity' approach to learning English as a second language takes into account the learner's membership in a community. As such, the learner may have an accepting attitude of his/her identity as a second- language learner, or the learner may reject this identity if it comes into conflict with the society's norms and aspirations (Amini, 2020; Wahid \& Pilus, 2017).

In Malaysia, the majority of the bilingual population use English language as the second language (Campbell, 2018). The English language is almost native in many colonized countries around the world, including pre-independent Malaysia. In 1967, despite the implementation of the National Language Policy in Malaysia and the process of the English language being slowly phased out as the primary medium of instruction in secondary and tertiary education, English is still essential to facilitate international trade, diplomacy, tourism and advancing the science and technology sector in the country. It had been outlined by Crismore et al. (1996) that English would play a large role in enabling the nation to achieve the goals of development and progress by the year 2020, a point which was reiterated by Selvaratnam (2019). In this current global era, Information Technology has made the English language paramount for most countries in the world and foreign investors prefer Englishspeaking countries (Selvaratnam, 2019). When the '80s came to Malaysia, the country's economic focus shifted from the agriculture sector to the industrial sector. In response to this new development, the Malaysian government emphasized on the learning of English to assist in gaining new knowledge and skills to better advance the country's economy. Globalization placed nations on a competitive level and 
both public and private organizations are pursuing competent graduates who are skilled in English.

\section{Existing Research}

The related studies in this section summarize the framework behind this study. The studies collectively discuss urban English learners, second language identity and English language and employment opportunities in Malaysia. Each of these studies is discussed in the following paragraphs.

On urban English learners, Gobel et al. (2013) conducted a descriptive study of Malaysian urban and rural students' attributions for success and failure in learning English as a second language. The findings indicated that urban and rural students held different attribution ratings for the success and failure for learning English as a second language with the urban group being more willing to attribute success to their own ability, effort, and study skills than the rural group. They hypothesized that the urban group was much more study-wise and confident as they had a greater belief in their own ability to take control of their successes in the language classroom.

In line with Swami and Furnham (2010), Kudrna et al. (2010) and Baharudin et al.'s (2010) research discovered that there were urban/rural and class differences in selfperception of intelligence, and differences in educational goals and academic achievement. Swami and Furnham (2010) examined inter-ethnic, rural-urban, and sex differences in self-assessed intelligence in a Malaysian general population sample. In general, results found that in a nation-wide study of self-assessed intelligence, that urban participants tended to have higher selfassessments than their rural counterparts. The study was further expanded in Kudrna et al. (2010). Baharudin et al.'s (2010) study examined connections between educational goals, parenting practices of single-mothers and single-fathers and the academic achievement of their adolescents. The results found that academic goals and academic achievement also varied based on location.

Moving on to second language identity, Besser and Chik (2014) conducted a study on understanding how young learners position themselves as speakers of a foreign language. Their study established that it was important to consider how educational policy, cultural values and the distribution of resources might impact young learners studying in similar contexts. This is paired with De Fina's (2012) study where she analyzed identities in sociolinguistics and applied linguistics from three discursive approaches. One studied primarily social identities, a second focused on personal or biographical identities, and the third pushed for a complication of established identity theories in the face of new developments in technology and the digital world. She stated that identities could be regarded as collective or individual, as social or personal, as mental constructs or as the product of actions. Her definitions of identity ties in well with Besser and Chik's (2014) study where they explained that learning resources formed an integral part of second language 
learning, ultimately forming one's second language identity. The study of secondlanguage identity and the motivation to learn English has also been explored in Malaysia, albeit rarely. A few studies suggested that among Malays, English usage beyond the classroom could constitute a threat to their Malay identity as a result of the belief that "Malayness" is defined not only by ethnicity and religion, but also the employment of the Malay language as well (Rajadurai, 2011; Wahid \& Pilus, 2017).

Block's (2007) empirical research links second language learning and identity that looks into Firth and Wagner's (1997) second language acquisition research. His study helped to identify factors of second language identity development. Block (2007, p. 872) mentioned in his study that he hoped to have shown how second language identity researchers had managed "to carve out a corner" for themselves in second language acquisition that did not exist 15 years before his study. The study also surmised that identity was still a key construct in second language acquisition research. In a similar context, Norton's (1997) study served as an introduction to the special-topic issue of the TESOL Quarterly on Language and Identity. The researcher illustrated the significant relationship among identity, language learning and classroom teaching. She drew on the issue as a whole to address the prevalent theme in many of the contributions, which was the ownership of English internationally.

On English language and employment opportunities in Malaysia, Sekharan Nair et al. (2012) investigated the possibility of lack of English proficiency contributing to poor market value among new graduates in Malaysia as well as to identify the aspects of the language proficiency skills that was most favored by the Malaysian work sector. The results surmised that the lack of English proficiency might lead to occupational segregation and affected employment prospects in Malaysia. Going back a few years before, Lim (2010) conducted a study aimed to develop statistical profiling models of low employability graduates in Malaysia. It was found that ethnicity, English language proficiency and types of degree obtained were significant predictors of graduates' employability which was measured either by the number of days being unemployed or the probability of being unemployed. One of the implications in his study was that English language proficiency was found to have a significant influence on graduates' employability. A qualitative study on employers' views found the English language proficiency was an important consideration in the customer service and marketing fields (Ting et al., 2017). A further study confirmed that more than $90 \%$ of employers and students in Malaysia agreed that English language proficiency was important for employment in Malaysia (Zainuddin et al., 2019).

The connection between urban English learner's second language identity and employment opportunities in Malaysia is one that is sparsely looked into. The review of previous studies on the combined topics of urban English learners, second 
language identity and English language and employment opportunities in Malaysia show that there is a gap in the literature, as most studies are based on either of the topics, mostly focusing on English language and employment opportunities. This study hopes to fill in the gap by finding a correlation between urban English learner's second language identity and their employment opportunities and prompting more research on this connection.

\section{METHODS}

This study is an exploratory study that aims to identify urban English learners' perceptions towards their second language identity in Malaysia. Subsequently, to investigate urban English learners' perceptions towards the influence of second language identity on employment opportunities in Malaysia. This study took on a qualitative research design, in which interviews were used to collect data from 12 participants. A semistructured interview was used to collect data with regards to the urban English learners' perceptions towards their second language identity and the influence of the said identity on employment opportunities in Malaysia.

\section{Participants and Sampling}

This study employed purposeful sampling, which according to Creswell (2012) is to intentionally select participants to learn and understand the central aspect of the study. The inclusion criteria are individuals between the ages of 19 to 35 , who are in Pre-University or have Pre-University qualification, have had at least one-year work experience, part-time or full time, and is currently living in Malaysian urban areas, defined by the Department of Statistics Malaysia as any gazetted area of more than $5 \mathrm{~km}$ radius with more than 10,000 inhabitants and with at least $60 \%$ of its inhabitants involved in non-agricultural activities (Department of Statistics Malaysia, 2020). The participants must also identify themselves as second-language speakers of English. The number of participants is determined by the saturation of data, upon the determination of which three more participants will be sampled (Francis et al., 2010). Table 1 below illustrates a brief background for the 12 participants.

Table 1

Demography and work experience of interview participants

\begin{tabular}{lccll}
\hline $\begin{array}{l}\text { Participant } \\
\text { (nickname) }\end{array}$ & Age & First Language & Educational Level & Work Experience \\
\hline Aminah & 25 & Bahasa Malaysia & Bachelor's Degree & $\begin{array}{l}\text { Internship at an aviation } \\
\text { company }\end{array}$ \\
Boy & 22 & Mandarin & Bachelor's Degree & $\begin{array}{l}\text { Part-time promoter at } \\
\text { shopping malls }\end{array}$ \\
& & &
\end{tabular}


Table 1 (Continued)

\begin{tabular}{|c|c|c|c|c|}
\hline $\begin{array}{l}\text { Participant } \\
\text { (nickname) }\end{array}$ & Age & First Language & $\begin{array}{l}\text { Educational } \\
\text { Level }\end{array}$ & Work Experience \\
\hline Chandri & 23 & Tamil & $\begin{array}{l}\text { Bachelor's } \\
\text { Degree }\end{array}$ & $\begin{array}{l}\text { Internship at kindergarten, } \\
\text { Part-time promoter \& } \\
\text { Part-time kindergarten } \\
\text { assistant teacher }\end{array}$ \\
\hline Dilah & 23 & Mandarin & $\begin{array}{l}\text { Bachelor's } \\
\text { Degree }\end{array}$ & $\begin{array}{l}\text { Internship at a Taiwanese } \\
\text { high school }\end{array}$ \\
\hline Elina & 22 & Cantonese & $\begin{array}{l}\text { Bachelor's } \\
\text { Degree }\end{array}$ & $\begin{array}{l}\text { Internship at board games } \\
\text { café \& Part-time sales } \\
\text { assistant }\end{array}$ \\
\hline Fang Yu & 22 & Cantonese & $\begin{array}{l}\text { Bachelor's } \\
\text { Degree }\end{array}$ & $\begin{array}{l}\text { Internship as content } \\
\text { writer }\end{array}$ \\
\hline Goya & 23 & Malayalam & $\begin{array}{l}\text { Bachelor's } \\
\text { Degree }\end{array}$ & $\begin{array}{l}\text { Part-time short film } \\
\text { director \& photographer }\end{array}$ \\
\hline Hilos & 25 & Uzbek & $\begin{array}{l}\text { Bachelor's } \\
\text { Degree }\end{array}$ & $\begin{array}{l}\text { Internship at a private } \\
\text { university }\end{array}$ \\
\hline Ivy & 23 & Mandarin & $\begin{array}{l}\text { Bachelor's } \\
\text { Degree }\end{array}$ & $\begin{array}{l}\text { Internship as marketing } \\
\text { executive }\end{array}$ \\
\hline Hasmin & 23 & Bahasa Malaysia & $\begin{array}{l}\text { Bachelor's } \\
\text { Degree }\end{array}$ & $\begin{array}{l}\text { Internship as museum } \\
\text { curator, marketing } \\
\text { executive \& project } \\
\text { manager }\end{array}$ \\
\hline Kay & 21 & Mandarin & $\begin{array}{l}\text { Bachelor's } \\
\text { Degree }\end{array}$ & Part-time English tutor \\
\hline Liu Hua & 23 & Mandarin & $\begin{array}{l}\text { Bachelor's } \\
\text { Degree }\end{array}$ & $\begin{array}{l}\text { Internship as kindergarten } \\
\text { assistant teacher }\end{array}$ \\
\hline
\end{tabular}




\section{Instrument and Location}

Individual semi-structured interviews were conducted on 12 participants who fulfilled the inclusion criteria. Creswell (2012) explained that one-on-one interviews were a type of individual interviews which was fitting for interviewing participants who were eloquent in expressing their ideas. LeCompte and Schensul (1999) maintained that a semi-structured interview allowed for further investigation into the central aspect as necessary. The interviews included questions that identified urban English learners' perceptions towards their second language identity and the influence of their second language identity on employment opportunities in Malaysia. The interview questions were adapted from Roshid and Chowdhury's (2013) study, which was a similar study on English language proficiency and employment among Bangladeshi graduates' success in finding employment in Australia. The five interview questions were:

1. What factors do you think are important for your second language identity and why?

2. Which factors do you think can affect your second language identity and how?

3. What are some of the useful resources for you to learn English? Do you think these resources generally affect your second language identity and how?

4. What language enables you to stand a higher chance of employment and why? 5.Did your English language help you in any employment opportunities and why?
The research aim and objectives were defined for the participants before the interview. As detailed in Eisner (2014), the participants were also asked for their opinions of 'what is a second language identity?' before being told the operational definition of second language identity for objective understanding on the topic. Follow up questions were posed as needed and the interviews ranged from 30 to 60 minutes. The interview questions have been moderated by experienced researchers. Location of the research was focused on Malaysian urban cities where employment opportunities, as well as youths seeking employment opportunities, are prevalent.

\section{Data Collection and Analysis Procedures}

Figure 1 shows the proposed conceptual framework of the study which guided the data collection and analysis process. The type of data that was collected in this study was the narrative discussion provided by the participants during the individual interview. The responses were audio-recorded and transcribed verbatim. This study employed the integrated approach for the data analysis to develop the code structure, where codes were derived to be compared to the study's theories as well as referring to initial codes prepared from literature related to this study. Curry (2016) explained that this approach maintains the advantages of inductive coding and accepted different types of codes that were useful in forming certain types of outputs. The themes and sub-themes 


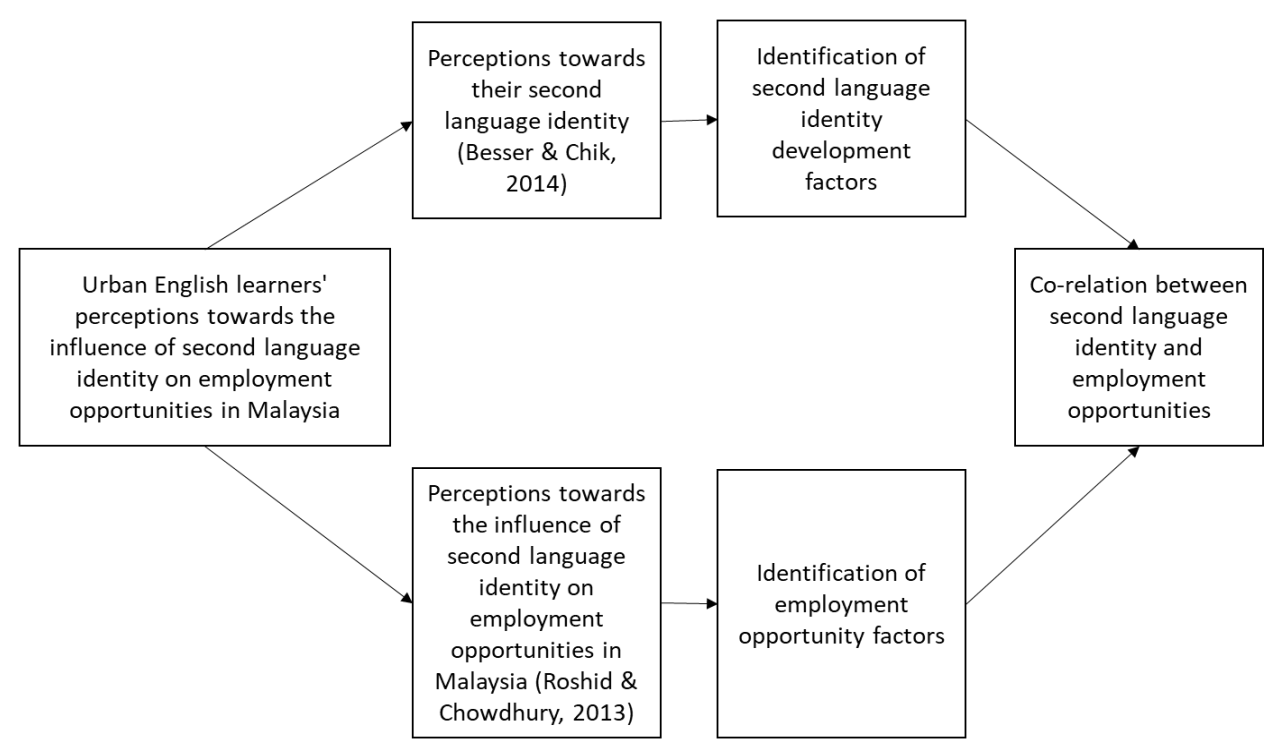

Figure 1. Conceptual framework of the study

were then generated by identifying patterns of themes from the codes. Two areas are investigated; perceptions towards their second language identity as suggested by Besser and Chik (2014) and perceptions towards the influence of second language identity on employment opportunities in Malaysia as suggested by Roshid and Chowdhury (2013). From the investigation of these two areas, comes the identification of second language identity development factors and employment opportunity factors. This then leads to affirming whether there is a correlation between second language identity and employment opportunities.

\section{RESULTS AND DISCUSSIONS}

The first research question identified the urban English learners' perceptions on their second language identity via second language identity development factors and useful English language learning resources. For the second research question, the urban English learners' perceptions towards the influence of second language identity on employment opportunities in Malaysia were identified via participants' personal perceptions on whether English language enabled higher chance of employment and whether English language proficiency and identity helped in employment opportunities. Table 2 illustrates the summary of findings.

\section{Perceptions on Their Second Language Identity}

Data analysis of the first research question revealed that urban English learners' perceptions on their second language identity via second language identity development factors were personal, social, 
Table 2

Summary of findings

Themes
Answers $R Q 1$ : Personal factors are
important for second language identity
development

Sub-themes

- to express oneself better

- strive for better English proficiency

- $\quad$ speaking English would be perceived as high class

- English empowers oneself

- to be able to use English around the world

- love and interest for English language

- to be perceived as well educated

Answers RQ1: Social factors are important for second language identity development

- to communicate with friends and lecturers

- to better present oneself

Answers RQ1: Professional factors are

- to communicate with clients and customers important for second language identity development

- employers usually interview in English

- English language is required in one's line of profession

Answers RQ1: Educational factors are

- to better understand information important for second language identity development

- English as a medium of instruction

- to communicate in class

- teachers teaching English using non-English language in schools

Answers RQ1: Learning environment may affect second language identity development

- friends and classmates in university speak English

- speaking English in high school would come off as arrogant

- learning English in schools was for the sake of exams

- university courses conducted in English

- family members recognizing the importance of English language

- participating in English related competitions 
Table 2 (Continued)

\begin{tabular}{|c|c|}
\hline Themes & Sub-themes \\
\hline $\begin{array}{l}\text { Answers } R Q 1 \text { : Place of living as a factor } \\
\text { that may affect second language identity } \\
\text { development }\end{array}$ & $\begin{array}{l}\text { English is used more often in cities like } \\
\text { Kuala Lumpur } \\
\text { hometown does not encourage using English } \\
\text { language } \\
\text { hometown did not have readily accessible } \\
\text { Internet for most families in the past }\end{array}$ \\
\hline $\begin{array}{l}\text { Answers RQ1: Useful resources to learn } \\
\text { English }\end{array}$ & $\begin{array}{ll}\text { - } & \text { social media } \\
\text { - } & \text { TV shows } \\
\text { - } & \text { YouTube videos } \\
\text { - } & \text { English movies } \\
\text { - } & \text { English cartoons } \\
\text { - } & \text { English songs } \\
\text { - } & \text { Dictionaries } \\
\text { - } & \text { online articles } \\
\text { - } & \text { socializing in English }\end{array}$ \\
\hline $\begin{array}{l}\text { Answers } R Q 1 \text { : English learning } \\
\text { resources may influence second } \\
\text { language identity development }\end{array}$ & 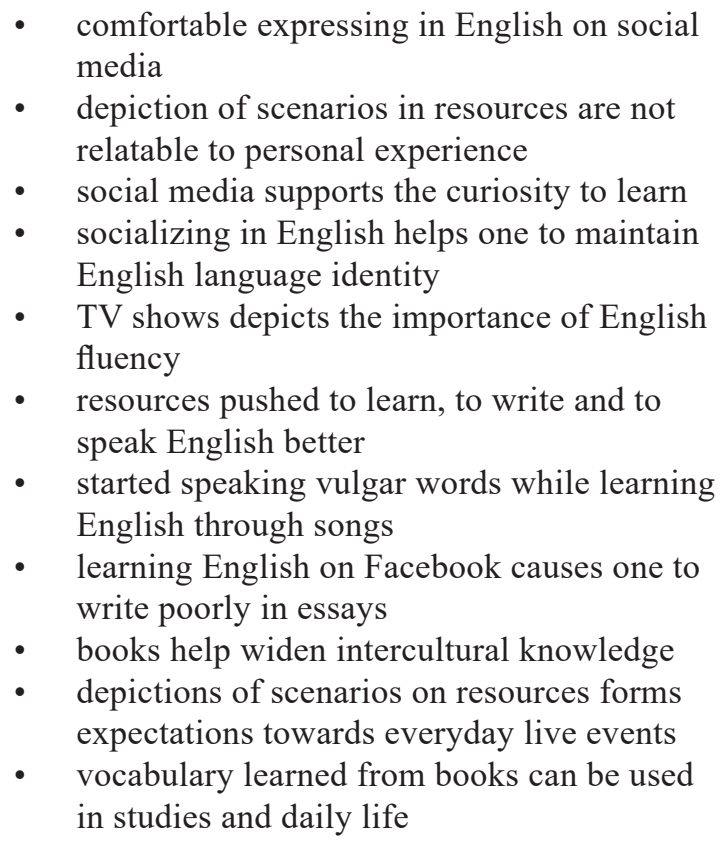 \\
\hline
\end{tabular}


Table 2 (Continued)

\begin{tabular}{|c|c|}
\hline Themes & Sub-themes \\
\hline $\begin{array}{l}\text { Answers } R Q 2 \text { : English language enables } \\
\text { higher chance of employment }\end{array}$ & 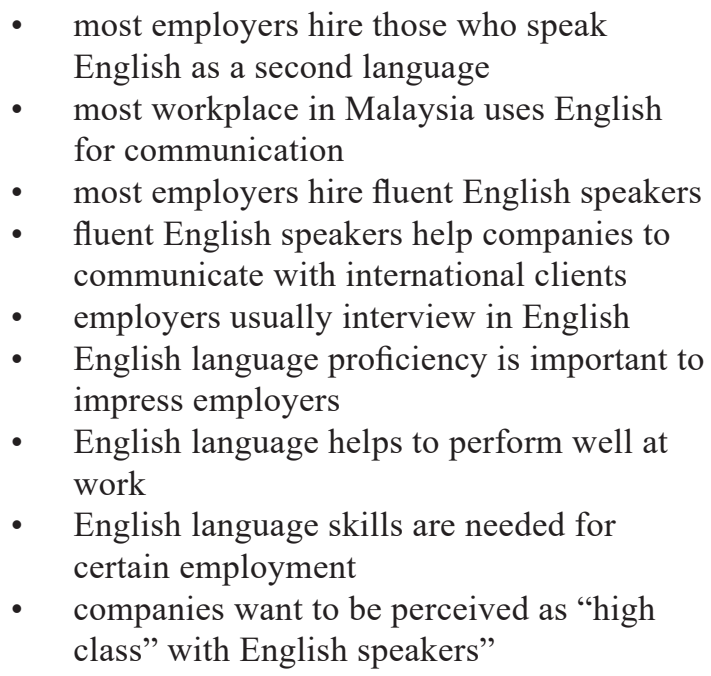 \\
\hline $\begin{array}{l}\text { Answers } R Q 2 \text { : English language } \\
\text { proficiency and identity help in } \\
\text { employment opportunities }\end{array}$ & $\begin{array}{l}\text { - } \text { given more responsibility at work because } \\
\text { of English proficiency } \\
\text { - } \quad \text { ideal job requires usage of English } \\
\text { - English language identity helps to improve } \\
\text { English education } \\
\text { able to understand the convey the } \\
\text { instructions in English } \\
\text { - to be able to communicate to international } \\
\text { clients } \\
\text { - level of English language fluency and } \\
\text { proficiency provides an advantage } \\
\text { more confident speaking English } \\
\text { to be perceived as well educated and } \\
\text { confident }\end{array}$ \\
\hline
\end{tabular}

professional, educational and learning environment. Participants' perceptions on useful resources to learn English and how those resources generally affected their second language identity also contributed to the first research question.

\section{Learning Environment Affects Second} Language Identity Development. Among the five-second language identity development factors, learning environment was the only factor that was cited by all 12 participants. The next most cited factor was social factor with 9 participants citing it, 
followed by professional and educational with 7 participants and personal with 6 participants respectively. While citing the learning environment might affect second language identity development, most participants elaborated that "speaking English in high school would come off as arrogant" and "learning English in schools was for the sake of exams" can affect one's second language identity. Such a finding is not unusual as such ideology was found to be persistent in the Malaysian context. Kim (2006) had found that using the English language was often being viewed as trying to "show off" and to boast oneself. Figure 2 below shows a participant's narrative that reiterates the point of discussion.

\section{Participant: Aminah}

"Because in high school, there's a restriction in not being able to have that identity to be honest. Because I come from Sekolah Menengah Kebangsaan so its mixed but because majority is Malay and back then people have this idea, that if you speak in English, you're trying to be a snob. You're trying to be snobbish, you know, you're not being yourself. Because they relate you very closely to your race, to your culture."

Figure 2. Participant's narrative on "speaking English in high school would come off as arrogant"

Next, the perception that learning English in schools was for the sake of exams was echoed in Chang and Goswami's (2011) study on factors that affected the implementation of communicative language teaching. Their study was conducted on Taiwanese college English classes, and they found that one of the factors that impeded the implementation was the "examoriented" style of teaching, where students were driven to utilize English language in an academic sense only. Figure 3 below shows a participant's narrative that reiterates the point of discussion.

\section{Participant: Boy}

"If we learn English, we learn the grammar, the punctuation, we learn how to spell the word, but we don't really learn how to use the language... "How are you?", "I am fine thank you, how are you?" "I am fine thank you too" [laughs] Like in my primary school, we may think that it is the only way to greet people. Because you don't really use it with the English talking people and like a formula you have to memorize, like a question must be followed by an answer. Like tag questions have a certain way to form the sentence at the end and how they should answer you, like if you ask "isn't it?" then you should answer "it is" right? That kind of work. like homework."

Figure 3. Participant's narrative on "learning English in schools was for the sake of exams" 
English Language-Learning Resources.

Moving on to participants' perception on useful resources to learn English and how those resources generally affect their second language identity also contributed to the first research question, the 12 participants stated social media, English TV shows, YouTube videos, English movies, English cartoons, English songs, English books, dictionaries, online articles and socializing in English as useful resources to learn English. The most cited resources are English books and English movies. The type of English books the participants read were mostly fantasy genres such as Harry Potter by J. K. Rowling, which was cited the most. The elaboration that the participants gave were that reading English books helped with widening vocabulary and learning new terms or phrases. Alsup (2010) stated in her book that an aspect of identity formation was embedded in literature and youth identity development was the notion of narrative identity. She explained that the stories one told about their personal experiences grew in detail as one moves through childhood and into adulthood. Hence, reading young adult literature, such as fantasy books may have an impact on one's identity development. This is also true in the context of this study, where some of the participants who grew up reading J. K. Rowling's Harry Potter, found traces of the experience in their second language identity. Figure 4 below shows a participant's narrative that reiterates the point of discussion.

\footnotetext{
Participant: Ivy

"For books, I think the easier way for you to learn is through, for example, short stories, novels, those kind of light reading, not like textbooks or exercise book because when you want to do the questions, you'll feel pressured, you wouldn't feel like you want to continue learning it, but like if you just read the story, enjoy the story, of course slowly it would improve your vocabulary. You improve your grammar...During my childhood, I read the Enid Blyton, I was attracted to the book cover at first actually because it's very cute. I read the books and also I read Harry Potter...the words that they use are also not complicated. So, it's easier to understand, as a teenager, it's easier for me to digest so that's why the interest developed from there."
}

How does these resources generally affect your second language identity?

"Yes, of course...I feel that my world is bigger because I am exposed to different cultures. Like for example, when I read Harry Potter maybe I know some UK cultures those sort of things...So my language identity it affects me in a way that I feel I enjoy English language class more than before. Yes because I discovered the joy of learning it. So, that is why I enjoy my English class more than I was before. I also observe the difference in the accent, for example, Harry Potter, they are UK accent right?...I feel that it's very formal and it attracts me the accent. But I don't really try to emulate in real life, I feel quite shy to emulate in real life."

Figure 4. Participant's narrative on English language fantasy books having an impact on one's identity development 
Next, the resource, English movies, most participants explained that while watching an English movie, having the subtitle on, be it English subtitles or another language's subtitles, helps with understanding the language better. Etemadi's (2012) study suggests that subtitled movies proved to be more efficient at developing listening comprehension. The study also suggests that subtitled movies help students learn a foreign language judging from improvement in reading and listening comprehension, word recognition, decoding skills and vocabulary acquisition. Figure 5 below shows a participant's narrative that reiterates the point of discussion.

\section{Participant: Liu Hua}

"I watch all kinds of movies and dramas and because mostly they are in Chinese. And then the subtitles will be in English. Because it's kind of like, it's not direct translation but then it teach you the word actually. Because they have Chinese subtitle and English subtitle, together. So when you don't know the word you can directly refer to the word up there, in Chinese. So I think it's very useful for learning English."

How does these resources generally affect your second language identity?

"I think it does. Because sometimes the academic word that you learn from essay books, you can actually use it in your essay writing during exam. So, you get higher marks, so your identity is kind of upgrade I'd say. And then for newspaper and books, the words that we learn from newspapers and subtitles all that, I think we can apply in daily life. So, it makes your speech more fluent."

Figure 5. Participant's narrative on English language movies as a useful resource to learn English

\section{Perceptions towards the Influence of Second Language Identity on Employment Opportunities}

Data analysis of the second research question revealed that all 12 of the participants stated that English was the language that enabled the higher chance of employment in Malaysia, and that their English language proficiency and identity helped in employment opportunities.

\section{English Language Enables Higher Chance of Employment in Malaysia. All} 12 of the participants stated that English was the language that enabled higher chance of employment in Malaysia. The most cited explanation was "most employers hire fluent English speakers", "English proficiency is important to impress employers" and "ideal job requires English language skills". This has been cited by studies on English language and employment in Malaysia in the past two decades, such as, Ball and Chik (2001), Sarudin et al. (2008), Lim (2010), Sekharan Nair et al. (2012), Roshid and Chowdhury's (2013), and Selvaratnam (2019). All these studies agreed that English language proficiency 
was crucial for employment in Malaysia and now with this study's participants nodding in unison as well. Figure 6 below shows a participant's narrative that reiterates the point of discussion.

\section{Participant: Hasmin}

"English. Because first of all, I am looking for employment in the private sector in Malaysia. And main language used when they're putting out job vacancies are usually in English especially for big companies. And companies that are looking to go international, they would usually be English. So being good in English will give you an advantage, to just be noticed by the employer especially if you have a good cover letter or your resume reflect correctly. So during interviews you can usually, in this companies, they will interview you in English. So if you're good in English, you can present yourself well, confident and I think that's highly attractive to those hiring managers."

Figure 6. Participant's narrative on English language enabling a higher chance of employment in Malaysia

English Language Identity Helped in Employment Opportunities. An interesting finding is that almost all of the participants stated that English language identity would help in employment because their ideal or dream job required language skills and identity. It is important to note that even though most of the participants are taking a university course in English, only four of them, Chandri, Fang Yi, Kay and Liu Hua intend to become an English educator in the future. Hence, it is peculiar that 11 out of 12 participants' ideal or dream jobs would, either directly or indirectly, require English language skills and/or identity. This would further strengthen this study's hypothesized connection between urban English learners' second language identity and their employment opportunities in Malaysia. Figure 7 below shows a participant's narrative that reiterates the point of discussion.

\section{Participant: Liu Hua}

"I think it does help me in my employment opportunities because when you speak English to them the first time, before interviews also, they would perceive you like, you are educated, you are presentable. And then they would give you like higher marks you know, during the interview. Even before they interview, they have a better impression of you just because you speak English. And then they would start asking you "Do you know how to differentiate between this or this?" They would look at you differently...They will think of you as.. "Yeah you can speak English, you're going to teach the students well." Even though they didn't check your grades. They would think of you as "OK. I think you're up for the job.", "

Figure 7. Participant's narrative on English language identity helping in employment opportunities 


\section{CONCLUSION}

This study has shown that it may take more than just English language proficiency to secure a job in today's working world. Because it is undeniable, especially in the Malaysian context, that English language proficiency and its attributes to employability is still a frequently discussed issue decades later, shown in Gaudart (1987) and 21 years later in Sarudin et al. (2008). This issue is also reiterated by Selvaratnam (2019). This study has thus, obtained relevant data that may fill in the research gap in fields regarding second language identity and employment opportunities. Supported by the English language identity development factors provided by the participants themselves, this study may provide English educators the latest or even more effective methods to teach English learners. This is applicable in today's context, as the world advances towards the fourth industrialization. Those resources mentioned by the participants in this study contain a few newer resources that many other non-native English learners may not have utilized while developing their language proficiency and identity. Researchers who are interested in further expanding this topic might consider obtaining a larger sample for qualitative data analysis. A larger sample would mean more time should be invested into the study. However, a larger sample would be paramount to further strengthen the connection between second language identity and employment opportunities. It would also be good to consider conducting a long-term project that involves participants noting down their narratives such as a photo-elicitation project, to use as data for furthering this research. This can provide a more detailed and in-depth narrative as well as perception.

\section{ACKNOWLEDGEMENT}

We would like to thank all the participants of this study.

\section{REFERENCES}

Ab Dollah, R., \& Shah, P. M. (2016). A comparison between vocabulary learning strategies employed by urban and rural schools students. Journal of Education and Social Sciences, 4, 114-121.

Alsup, J. (Ed.). (2010). Young adult literature and adolescent identity across cultures and classrooms: Contexts for the literary lives of teens. Routledge. https://doi. org/10.4324/9780203853139

Amini, A. (2020). Social identity: A composite concept in Social Sciences research. Journal of Social Sciences and Humanities Research, 8(3).

Baharudin, R., Hong, C. Y., Lim, S. J., \& Zulkefly, N. S. (2010). Educational goals, parenting practices and adolescents' academic achievement. Asian Social Science, 6(12), 144-152. https://doi. org/10.5539/ass.v6n12p144

Ball, R., \& Chik, R. (2001). Early employment outcomes of foreign and educated graduates: The Malaysian experience. Higher Education, 42(2), 171-189. https://doi. org/10.1023/A:1017579415737

Benson, P., Barkhuizen, G., Bodycott, P., \& Brown, J. R. (2013). Second language identity in narratives of study abroad. Palgrave Macmillan. https://doi. org/10.1057/9781137029423

Besser, S., \& Chik, A. (2014). Narratives of second language identity amongst young English 
learners in Hong Kong. ELT Journal, 68(3), 299309. https://doi.org/10.1093/elt/ccu026

Block, D. (2007). The rise of identity in SLA research, post Firth and Wagner (1997). The Modern Language Journal, 91, 863-876. https://doi. org/10.1111/j.1540-4781.2007.00674.x

Campbell, J. (2018). English language and an inclusive Malaysia. 3L: The Southeast Asian Journal of English Language Studies, 24(3), 206219. http://doi.org/10.17576/3L-2018-2403-15

Chang, M., \& Goswami, J. S. (2011). Factors affecting the implementation of communicative language teaching in Taiwanese college English classes. English Language Teaching, 4(2), 3-12. https:// doi.org/10.5539/elt.v4n2p3

Creswell, J. (2012). Educational research planning, conducting, and evaluating quantitative and qualitative research (4th ed.). Pearson.

Crismore, A., Ngeow, K. Y. H., \& Soo, K. S. (1996). Attitudes toward English in Malaysia. World Englishes, 15(3), 319-335. https://doi. org/10.1111/j.1467-971X.1996.tb00118.x

Curry, L. (2016). Fundamentals of qualitative research methods [Video]. Yale University. https://www. youtube.com/watch?v=wbdN_sLW188

De Fina, A. (2012). Discourse and identity. The Encyclopedia of Applied Linguistics, 1-8.

Department of Statistics Malaysia. (2020). Population and Housing Census. https://www.dosm.gov.my/ $\mathrm{v} 1 /$ index.php? $\mathrm{r}=$ column/cone\&menu_id=bDA2 VkxRSU40STcxdkZ4OGJ0c1ZVdz09

Eisner, E. (2014). Objectivity in educational research. Curriculum Inquiry, 22(1), 9-15. https://doi.org/ 10.1080/03626784.1992.11075389

Etemadi, A. (2012). Effects of bimodal subtitling of English movies on content comprehension and vocabulary recognition. International Journal of English Linguistics, 2(1), 239. https://doi. org/10.5539/ijel.v2n1p239
Firth, A., \& Wagner, J. (1997). On discourse, communication, and (some) fundamental concepts in SLA research. The Modern Language Journal, 81(3), 285-300. https://oi. org/10.1111/j.1540-4781.1997.tb05480.x

Francis, J. J., Johnston, M., Robertson, C., Glidewell, L., Entwistle, V., Eccles, M. P., \& Grimshaw, J. M. (2010). What is an adequate sample size? Operationalising data saturation for theory-based interview studies. Psychology and Health, 25(10), 1229-1245. https://doi. org/10.1080/08870440903194015

Gaudart, H. (1987). English Language Teaching in Malaysia: A historical account. The English Teacher, 16(1987), 17-36.

Glaeser, E. L. (1999). Learning in cities. Journal of Urban Economics, 46(2), 254-277. https://doi. org/10.1006/juec.1998.2121

Gobel, P., Thang, S. M., Sidhu, G. K., Oon, S. I., \& Chan, Y. F. (2013). Attributions to success and failure in English language learning: A comparative study of urban and rural undergraduates in Malaysia. Asian Social Science, 9(2), 53-62. https://doi.org/10.5539/ ass.v9n2p53

Hanapi, Z., \& Nordin, M. S. (2014). Unemployment among Malaysia graduates: Graduates' attributes, lecturers' competency and quality of education. Procedia-Social and Behavioral Sciences, 112(2014), 1056-1063. https://doi.org/10.1016/j. sbspro.2014.01.1269

Kim, L. S. (2006). Masking: Maneuvers of skilled ESL speakers in postcolonial societies. In A. Hashim \& N. Hassan (Eds.), English in South East Asia: Prospects, perspectives and possibilities. University of Malaya Press.

Kudrna, L., Furnham, A., \& Swami, V. (2010). The influence of social class salience on self-assessed intelligence. Social Behavior and Personality: An International Journal, 38(6), 859-864. https:// doi.org/10.2224/sbp.2010.38.6.861 
LeCompte, M., \& Schensul, J. (1999). Analyzing \& interpreting ethnographic data. Altamira.

Lim, H. E. (2010). Predicting low employability graduates: The case of University Utara Malaysia. The Singapore Economic Review, 55(03), 523-535. https://doi.org/10.1142/ s0217590810003870

Norton, B. (1997). Language, identity, and the ownership of English. TESOL Quarterly, 31(3), 409-429. https://doi.org/10.2307/3587831

Norton, B., \& McKinney, C. (2011). An identity approach to second language acquisition. In D. Atkinson (Ed.), Alternative approaches to Second Language Acquisition (pp. 73-94). Routledge.

Rajadurai, J. (2011). Crossing borders: The linguistic practices of aspiring bilinguals in the Malay community. Australian Review of Applied Linguistics, 34(1), 24-39. https://doi.org/10.1075/ aral.34.1.02raj

Roshid, M. M., \& Chowdhury, R. (2013). English language proficiency and employment: A case study of Bangladeshi graduates in Australian employment market. Mevlana International Journal of Education, 3(1), 68-81.

Sarudin, I., Zubairi, A. M., Nordin, M. S., \& Omar, M. A. (2008). The English language proficiency of Malaysian public university students. In Enhancing the Quality of Higher Education Through Research: Shaping Future Policy (pp. 40-65). The Ministry of Higher Education (MOHE) Malaysia.

Sekharan Nair, G., Rahim, R., Setia, R., Husin, N., Sabapathy, E., Abd Jalil, N., Razlan, R. M., Mohamad, R., Mat So'od, S. M., Md Yusoff, N. I., Mohamed, N. M., \& Abu Seman, N. (2012). Malaysian graduates English adequacy in the job sector. Asian Social Science, 8(4), 143-147. https://doi.org/10.5539/ass.v8n4p143
Selvaratnam, V. (2019). Malaysia: National language policy and employability. International Higher Education, 96(Winter), 16-18. https://doi. org/10.6017/ihe.2019.96

Swami, V., \& Furnham, A. (2010). Self-assessed intelligence: Inter-ethnic, rural-urban, and sex differences in Malaysia. Learning and Individual Differences, 20(1), 51-55. https://doi. org/10.1016/j.lindif.2009.11.002

Ting, S. H., Marzuki, E., Chuah, K. M., Misieng, J., \& Jerome, C. (2017). Employers'views on importance of English proficiency and communication skill for employability in Malaysia. Indonesian Journal of Applied Linguistics, 7(2), 315-327. https://doi. org/10.17509/ijal.v7i2.8132

Wahid, R., \& Pilus, Z. (2017). Learning English in a third space? Malay students in an Englishspeaking university in Malaysia. Journal of Social Sciences \& Humanities, 25(3), 1167-1180.

Zainuddin, S. Z. B., Pillai, S., Dumanig, F. P., \& Phillip, A. (2019). English language and graduate employability. Education+Training, 61(1), 7993. https://doi.org/10.1108/ET-06-2017-0089 
